\title{
Waldemar Cisło
}

ORCID: https://orcid.org/0000-0003-1525-0945

Cardinal Stefan Wyszyński University in Warsaw,

Poland

\section{Persecution of Christians}

\begin{abstract}
The situation of Christians in Iraq and Syria has been problematic for many years. The article first deals with the issues of social tensions caused by religious diversity. The repercussions of these conflicts are presented, with an emphasis on the problems of immigration from regions affected by the war. The article then describes the forms of aid provided in Iraq and Syria, with an emphasis on medical and humanitarian aid. The work also includes reports from these places and outlines the problems of Christian clergy in persecuted communities.
\end{abstract}

\section{Keywords}

Syria, Iraq, aid, Christians, refugee camps

\section{Martyrdom of Syria}

\subsection{Religious situation}

Before the outbreak of war, Syria was one of the most peaceful countries, even for religious minorities. The country has a population of 22 million. Ethnically, the population of Syria is $86 \%$ Arabs, $7 \%$ Kurds, 3\% Armenians. In religious 
terms, Islam constitutes about $90 \%$ with Christianity taking up the remaining $10 \%$. The denominations of Islam found in Syria are: Sunni, Alawite, Druze and several other smaller groups. Thanks to the strong hand of the government in Syria, religious minorities enjoyed protection. This was manifested by the fact that the president maintained good relations with the highest ranking members of the Churches in Syria. Relations between Christians and Muslims were fundamentally cordial. St. John Paul II during his visit to Lebanon said that this country would remain an unsurpassed model of Christian-Muslim relations and an example of how they can live together while maintaining mutual respect and what they should look like. ${ }^{1}$ In Lebanon, a rule was established that the president is a Christian, the prime minister is a Sunni and the head of parliament is a Shiite. After the Holy Father's visit, this principle was included in the constitution. This stable situation continued until the Arab Spring. ${ }^{2}$

\subsection{The humanitarian situation of the people of Syria}

According to international organizations, more than 8.2 million Syrians have become external or internal refugees. Internal emigration concerns mainly the movement of people from war-affilicted areas to areas where there were no hostilities. One of the more peaceful places that did not suffer from the war is the diocese of Tartus. Iraq was also a place of refuge for Syrians, where it is estimated that it accepted about 300,000 refugees from Syria. Jordan accepted around 700,000, Lebanon received (estimates are divergent) from 1.2 million to 2 million people and 2.7 million Syrians found refuge in Turkey.

Particular attention should be paid to the situation in Lebanon, which has 4.5 million inhabitants. According to international organizations, this country has accepted around 800,00o refugees from Palestine and according to various data up to 2 million refugees from Syria. This situation causes a lot of tension in Lebanon itself.

Firstly, there are no official refugee camps there. Christian refugees gathered mainly in the Bekaa Valley region (on the Syrian-Lebanese border). There, thanks to the Catholic Church, the organization Aid to the Church in Need has been helping refugees from the very beginning. This includes running

\footnotetext{
https://kosciol.wiara.pl/doc/4164107.Liban-to-przeslanie/2 (01.07.2020).

https://teologiapolityczna.pl/ks-prof-waldemar-cislo-sytuacja-w-iraku-czy-syrii-nosiznamiona-holokaustu (25.06.2020).
} 
a kitchen where refugees can get a free meal, providing clothes for winter and summer, help with the purchase of heating oil and hygiene products. Lebanon, being a relatively poor country, would not be able to help the refugees without outside help. Lack of work and the possibility of earning money has led to even greater conflicts. For many years, external aid has saved Lebanon from riots and internal protests.

In December 2019, the banking system collapsed and people with even those with foreign currencies could withdraw only $\$ 100$ per family. This, of course, caused a lot of trouble for many families. The rapid rise of unemployment also caused waves of resentment towards refugees as those who are causing salary cuts by taking up jobs at low rates. Desperate people also went about stealing food and clothing because they had no money to buy it for themselves and their children. The situation of external refugees varies depending on the country where they reside. While the situation in Lebanon has deteriorated dramatically in recent months, it has not changed much in Jordan.

The biggest problem, however, is the length of the war. The civil war in Syria has been going on for almost 10 years, which is why international opinion is starting to show indifference to this fact. ${ }^{3}$

\subsection{Scale of aid}

Since the outbreak of war, the organization Aid to the Church in Need has been helping Syrians. The sum of the yearly support amounted to around EUR 3 million. Such great support for one country was caused by the dramatic conditions that prevailed there. Sister Anna, who thanked Poles for help at the press conference in Poland, said: „If not for food parcels financed, among others, by Poles, hundreds, if not thousands, would starve."

Such a dramatic situation prevailed during the initial stages of the war, in Aleppo for instance. During my visit to this city, I had the opportunity to personally check how the aid system works. Sister Annie gathered a large group of young volunteers, each of whom looked after from five to twenty families. Depending on the time, they declared that they would bring food and other necessary things to the families whom they were responsible for. These volunteers mainly looked after elderly people who either could not leave the house or was too difficult for them to carry a heavy food package from the church.

${ }^{3}$ https://pkwp.org/newsy/syria_9_lat_po_wojnie (24.06.2020). 


\subsection{Medical aid}

As in every other Middle East country, in Syria health care is based on private hospitals and outpatient clinics for which you have to pay. Bearing in mind high unemployment and inflation ${ }^{4}$, we can easily understand that providing medical care for families was also very difficult. ${ }^{5}$

Upon finding out there are many orphans in Aleppo in need of medical care, aid from Poland has been initiated. According to data received from local doctors during the war, and also after the siege of Aleppo, in this city alone 20,000 limbs were amputated.

The Polish Government, through the Father Werenfried Foundation, donated PLN 1.5 million to finance children's prostheses in Aleppo. After the very good reception of this program by local authorities and considering this fact, Prime Minister Beata Szydło decided to continue this project, named „Treatment of Syrians". The following year, the Prime Minister transferred PLN 5 million for support to such places as Tartus, Marmarita, Damascus, Homs and many others. In the second year of this program, 7200 people were treated. In practice, a man who received a referral from the hospital for one or another procedure, came to the parish asking for support. If he could, he partly covered the costs of this surgery. If not, it was fully covered by the Polish government.

I trust that after easing the restrictions associated with the coronavirus pandemic in Europe, we will be able to return to the Syrian treatment project again.

\section{Forgotten Iraq}

\subsection{Description of the situation}

Iraq is one of the countries in the world where the situation of Christians is most dramatic. In 2003, there were about 1.5 million Christians belonging to different Churches. At the time of writing, the number does not exceed 100,000. When we were with the Archbishop Gądecki in Baghdad, we visited the head of the Chaldean Church, Cardinal Louis Raphael Sako. In answer to my question,

${ }^{4}$ https://www.tvp.info/39996471/ks-waldemar-cislo-w-syrii-jest-szansa-na-normalnosc (29.06.2020).

5 https://pkwp.org/newsy/nadzwyczajne_wsparcie_dla_chrzescijan_w_syrii_i_pakistanie (24.06.2020). 
whether their life improved significantly after the intervention of the coalition forces, the patriarch took my arm, pointed to destroyed Baghdad and said: „During the reign of the dictator, we did not have full freedom, we lacked various things from the West on which an embargo was imposed, but we had electricity, schools, hospitals. Our wives, mothers and sisters, went shopping, came back alive. It was not like nowadays, every now and then we receive information that 10, 20, 100 people were killed in the bombing. By taking this relative peace from us, you gave us one thing in return: the option of throwing the card into the ballot box every few years. The price of this "democracy” are our destroyed cities, a country plunged into war and facing the threat of splitting into three parts. A weak government cannot deal with all these problems.

\subsection{Situation of Christians}

One of the groups that suffered the most as a result of the hostilities is the Christians. When the coalition forces invaded Iraq and killed the dictator Saddam Hussein, Muslims raised a rebellion claiming that the Crusader forces had attacked their homeland. Unfortunately, there was not enough concern on the part of the coalition forces for those Christians who helped the troops as translators, medical or technical staff. As soon as it became apparent that the person was helping the coalition forces, a death sentence was issued on him. What is emphasized by many observers is the fact that the coalition forces failed to create a reasonably stable, strong government that would manage to rule Iraq. Living conditions also deteriorated significantly, as many Christians from regions such as the Nineveh plain (a place inhabited mainly by Christians) were driven out. ${ }^{6}$ According to tradition, Christianity was brought to the cities around Mosul by Jews who were present during the Pentecost in Jerusalem. Therefore, the emergence of Christian communities around Mosul dates back to the first century after Christ.

The problem of Christians in Iraq escalated in 2014, when Christians were expelled from cities such as Bartala, Batnaya or Mosul. The head of the Chaldean Church, Patriarch Sako, alerted us in 2014, about 200,00o people were expelled literally in what they slept in. ${ }^{7}$

6 https://pkwp.org/newsy/irak_edukacja_i_dialog_kluczem_do_pozostania_w_kraju (24.06.2020).

https://pkwp.org/newsy/szesc_lat_od_wypedzenia_chrzescijan_z_mosulu (24.06.2020). 
To this day, Iraq is our priority as to where humanitarian aid is provided. One of the problems of Christians in Iraq is the large number of different Churches, both united with Rome and the Orthodox Churches. They are gathered in an ecumenical council that aims to facilitate cooperation and facilitate the distribution of humanitarian aid. This council is called the Council of Superiors of the Christian Communities in Iraq and consists of fourteen superiors of different religious groups. ${ }^{8}$

\subsection{Refugee camps}

Refugee camps were the next stage in organizing the lives of expelled Christians. Church squares were used to create them. We have seen a kind of evolution in the life of these camps. Initially, they were makeshift tents made of various cut sacks or other similar materials. In the second stage, tents made of strong foil appeared, which were bought by aid organizations. They created a waterproof shelter and also provided better comfort of accommodation. The last stage were containers. Such camps numbered from several hundred to over a dozen thousand people. To illustrate the organization of the camp's life we will use the example of one run by Father Douglas at one of the churches in Irbil. Since the beginning of the crisis, the priest has accepted 730 people there. Thanks to his resourcefulness, from the very beginning a large bathroom with toilets, a large playground for children and a school were organized in this camp, as well as a shared large kitchen where food for everyone was prepared. It was a model camp for us, because it satisfied all the basic needs of refugees.

Ensuring food and hygiene was an equally important element, which is why the Polish section of Aid to the Church in Need took patronage, financing all necessary needs at the camp run by Father Douglas. ${ }^{9}$ Today, there is no trace of this camp, because most of these people systematically found a flat and work in Irbil, which gave us the two most desirable effects. The first: Christians remained in place, the second: they were aware that there would always be someone to take care of them, if necessary. Even if they had problems, e.g. someone lost their jobs for a month or two, for that period they received support from the Church and could support their family and home. The importance of this awareness of caring for them is demonstrated by a specific survey conducted among refugees.

\footnotetext{
https://info.wiara.pl/doc/438182.Irak-W-chrzescijanskiej-jednosci-sila (25.06.2020).

9 https://pkwp.org/kampanie/oboz_w_erbilu (25.06.2020).
} 


\subsection{Medical aid}

Similarly to Syria, we also tried to provide medical care to Iraqi refugees. In Kurdistan, it was easier to provide help as there was no embargo, so one could simply reach Irbil by plane. A makeshift hospital was created, where Dominican sisters, to the best of their abilities, provided medical care to those in need.

However, the program proposed by Father Douglas was equally important. It consisted of conducting therapeutic classes with children who experienced the atrocities of war and were in trauma.

Here, psychology students from various countries, such as Canada, France and Belgium, came to the rescue. They came to Irbil in small groups and conducted classes with victims of war. This was extremely important, because as it turned out, many of these children only after some time opened up and released the burdens resulting from the cruelty of war.

\subsection{The role of clergy in persecuted communities}

Among the information that came to us from Iraq, we also received sad news about the fate of priests and nuns. Many of them risked their lives by remaining with their communities. In Poland, the case of Father Douglas Al-Bazi is well known. This priest was kidnapped in Baghdad during the celebration of Mass. For the first 5 days he was not given a drop of water or a slice of bread ${ }^{10}$. Islamic fanatics broke his teeth and with a hammer broke his bones to break him and force him to convert to Islam, whilst listening to verses of Koran recited on TV. When his bishop managed to contact the kidnappers, the situation improved slightly. After confirming that no ransom would be paid for him, it was decided they would release him. He was dressed in women's robes and left on the street with the instruction that he must not look back for the next 10 minutes, under threat of being shot. After this time, he went to his parish and we began his treatment, which lasted for several months. The remnant of the period of imprisonment is that before going to sleep he puts a water pack near the bed. This is just one example of how the priests, who remained with their faithful to the end, had to pay a high price.

In addition to many negative effects, the war in both Syria and Iraq has shown the importance of nuns and priests to the parish communities.

${ }^{10}$ P. Stachnik, Imigranci u bram, Biały Kruk, Kraków 2017, s. 82. 


\section{Conclusion}

The situation of Christians in Iraq provides us with a certain picture of Christianity in the Middle East. As Archbishop Warda from Erbil said: „We do not build beautiful churches or expensive buildings, because pogroms of Christians take place every 30-40 years". Christianity in those parts dates back to the first century after Christ and it managed to survive for many centuries. It is also worth considering the words of Bishop Warduni from Baghdad: "We all keep asking how is it possible that we are witnessing such unworthy actions: acts against God and man. Strong opposition to the actions of the jihadists who break people's consciences is required. They donot spare anyone. They attack children, old and sick people. We discussed this with the President of Kurdistan, who assured us that Christians would always find protection there. I would like to ask representatives of the world's various human rights organizations: why are you silent, why are you not standing up for Christians?! After all, they also have their rights! Where are they now? We want to shake the world's conscience! Where is Europe now, where is America? Let me remind you that Christians and Muslims have been living together on this earth for 1400 years. We are begging the world to help us stop selling."

The 21st century unfortunately shows that what has been successful so far may be difficult to maintain.. As Patriarch Sako said: „If Christians emigrate from Iraq at such a pace (2003 - 1.5 million Christians, and currently less than 100 thousand and about 40 thousand drop annually), then in a few years Iraq will be left without its Christian community. The Christians there often made it clear to Christians in Europe through their bishops that we had forgotten them too easily. Often these were bitter words that reminded us of our duty to care for persecuted brothers and sisters. „Similar statements in the presence of Iraqi bishops during the congress in Budapest were expressed by Hungarian Prime Minister Viktor Orban that Europe prefers not to see or hear what is happening in Iraq and other places where Christians are persecuted, because, as Orban said, we believe that such phenomena will not reach Europe. This failure to acknowledge the situation that prevails in many regions of the world is due to the fact that we do not want to react to it. Orban warned that this situation could reach Europe sooner than we thought, and that Pope Benedict's words that Christians would be a little flock in Europe could be fulfilled sooner than we thought ${ }^{11}$.

11 https://misyjne.pl/czy-benedykt-xvi-przewidzial-przyszlosc-kosciola-katolickiego/ (29.06.2020). 


\section{Bibliography}

\section{Books}

Stachnik P., Imigranci u bram, Biały Kruk, Kraków 2017.

\section{Websites}

https://teologiapolityczna.pl/ks-prof-waldemar-cislo-sytuacja-w-iraku-czy-syrii-nosiznamiona-holokaustu (25.06.2020).

https://kosciol.wiara.pl/doc/4164107.Liban-to-przeslanie/2 (01.07.2020).

https://pkwp.org/newsy/syria_9_lat_po_wojnie (24.06.2020).

https://www.tvp.info/39996471/ks-waldemar-cislo-w-syrii-jest-szansa-na-normalnosc (29.06.2020).

https://pkwp.org/newsy/nadzwyczajne_wsparcie_dla_chrzescijan_w_syrii_i_pakistanie (24.06.2020).

https://www.premier.gov.pl/wydarzenia/aktualnosci/premier-beata-szydlo-polski-rzadwlacza-sie-w-koscielna-inicjatywe-pomocy-dla.html (24.06.2020).

https://wnet.fm/2020/01/16/ks-prof-cislo-w-iraku-bylo-15-mln-chrzescijan-teraz-jest120 -tys/ (29.06.2020).

https://pkwp.org/newsy/irak_edukacja_i_dialog_kluczem_do_pozostania_w_kraju (24.06.2020).

https://www.catholicweekly.com.au/ministering-in-the-shadow-of-isis-was-the-besttime-of-my-life-says-sydney-based-archbishop-of-mosul/ (30.06.2020). https://pkwp.org/newsy/szesc_lat_od_wypedzenia_chrzescijan_z_mosulu (24.06.2020). https://info.wiara.pl/doc/438182.Irak-W-chrzescijanskiej-jednosci-sila (25.06.2020). https://pkwp.org/t/felietony/kaplani_i_ofiary (24.06.2020). https://pkwp.org/kampanie/oboz_w_erbilu (25.06.2020). https://misyjne.pl/czy-benedykt-xvi-przewidzial-przyszlosc-kosciola-katolickiego/ (29.06.2020). 